\title{
Qloballaşma şəraitində dilin inkişaf tendensiyaları və təhlükəsizliyi
}

\author{
Səyyar Abdullayev ${ }^{1}$, Tofiq Kazımov ${ }^{2}$, Südabə Abasova ${ }^{3}$ \\ AMEA İnformasiya Texnologiyaları İnstitutu, Bakı, Azərbaycan \\ ${ }^{1}$ sayyar.abdullayeveyandex.ru, ${ }^{2}$ tofig@mail.ru, ${ }^{3}$ abasova.sudaba@gmail.com,
}

\begin{abstract}
Xülasə - Məqalədə qloballaşan dünyada dil təhlükəsizliyi anlayışına milli təhlükəsizlik, informasiya təhlükəsizliyi, linqvistik suverenlik vo dil siyasəti problemlori kontekstində baxılır. Qloballaşma şəraitində dilin inkişaf tendensiyasına təsir edən amillər, onun milli saflığının qorunmasında terminlərin rolu və təhlükəsizliyinin təmin olunması məsələləri araşdırılmışdır.
\end{abstract}

Açar sözlor - dil tohlükosizliyi; qloballaşma; terminoqrafiya; linqvistik suverenlik; sosiolingvistika

\section{GİRiș}

Azərbaycan dili qədim tarixi köklərə malikdir. Ümummilli lider Heydər Oliyevin 9 avqust 2001-ci il tarixdə imzaladığ "Dövlət dilinin tətbiqi işinin təkmilləşdirilməsi haqqında" fərmanda deyilir: "Azərbaycan dili bu gün dərin fikirləri ən incə çalarlarınadək olduqca aydın şəkildə ifadə etmək qüdrətinə malik dillərdəndir. Düşüncələrdəki dərinliyi, hisslərdəki incəlikləri bütünlüklə ifadə etmək kamilliyinə yetişə bilməsi üçün hər hansı xalqda bir neçə minillik tarixi yaşaması lazım gəlir. Azərbaycan dilinin bugünkü inkişaf səviyyəsi göstərir ki, Azərbaycan xalq1 dünyanın ən qədim xalqlarındandır". Böyük uzaqgörənliklə imzalanan bu tarixi fərmana əsasən hər il avqust ayının 1-i Azərbaycan Olifbası və Azərbaycan dili günü kimi qeyd edilir.

Müasir dünyada gedən qloballaşma prosesləri Azərbaycana da öz təsirini göstərməkdədir. Milli varlığımız sayılan dilimizin təmizliyini, orijinallığını qoruyub saxlamaq, onun təbii inkişafina mane olan mənfi amillərin təsirini minimuma endirmək, dünya dilləri sirasında onun nüfuzunu yüksəltmək hamımızın müqəddəs vənəndaşlıq borcudur. Ölkəmizdə Azərbaycan dilinin hərtərəfli inkişafi, işlək dilə çevrilməsi, beynəlxalq münasibətlər sisteminə yol tapması Ana dilimizin gözəl bilicisi, mahir natiq ulu öndər Heydər Oliyevin dilin qorunmasına yönələn düşünülmüş siyasətinin nəticəsidir.Yeni ictimai-siyasi görüşlər, elm və mədəniyyətin sürətli inkişafi, orta və ali məktəblərin, elmi-tədqiqat müəssisələrinin təşkili, mətbuatın sayının artması, dərsliklərin, elmi əsərlərin Azərbaycan dilində yazılması dilin ictimai funksiyasının genişlənməsinə təkan vermişdir. 1995-ci ildə ümumxalq səsverməsi yolu ilə qəbul edilən müstəqil dövlətimizin ilk Konstitusiyası ilə dövlət dilinin adı bərpa edildi. Bu, ulu öndərin Ana dilimizə dəyişməz mövqeyinin daha bir parlaq nümunəsi oldu.
Azərbaycan əlifbası XX əsrdə üç dəfə dəyişdirilmişdir. Azərbaycan dilində yazı 1929-cu ilə kimi ərəb qrafikası ilə aparılmışdır. 1922-1939-cu illərdə latın qrafikalı əlifba üzrə (1929-cu ilə kimi ərəb əlifbası ilə paralel olaraq), 1939-1991-ci illərdə kiril qrafikası üzrə, 1991-ci ildən başlayaraq yenidən latın qrafikası üzrə aparılmışdır. Təbii ki, bu ədəbi, elmi dilimizin və onun terminoloji bazasının, ümumiyyətlə dilimizin inkişafına neqativ təsirlərini göstərir.

\section{QLOBALLAŞMADA DİLIN İNKIŞAFINA TOSİR EDON AMILLOR}

Qloballaşma şəraitində millətlərin milli varlığının aqibəti baxımından, dilin inkişaf perspektivlərinin prinsipial aspektləri və bu inkişafa təsir edən amillər aşağıdakı kimi təyin olunur.

Qloballaşma prosesi cəmiyyətin və insan fəaliyyətinin bütün sahələrinə nüfuz etməkdədir. $\mathrm{Bu}$ davamlı proses həm müsbət, həm də mənfi təsir xüsusiyyətlərinə malik olmaqla müxtəlif inkişaf səviyyəli ölkələrdə fərqlidir.

Geniş miqyasl1, hərtərəfli və ziddiyyətli xarakterinə görə qloballaşma dünya xalqlarında dil və mədəniyyət, adət və ənənələrin itirilməsi təhlükəsini yaradır. Qloballaşma subyektlərinin qarşılıqlı münasibətlərinə müasir informasiya kommunikasiya vasitələri, xüsusilə İnternet geniş müdaxilə edir. Qloballaşma həm də millətlərin yaxınlaşması və birbirinin həyat tərzini götürərək ona oxşamasıdır. Bu zaman milli mədəniyyətlərin inkişafı və onların spesifikliyinin qorunması məsələləri xüsusi diqqət mərkəzində olmalıdır.

Qlobal kommunikasiya sistemləri dünyanın bir sıra ölkələrində özünü dil ekspansiyanın ötürücüsü kimi də göstərir. Ona görə də qlobal tendensiyaların dilə neqativ təsirlərini minimuma endirmək məqsədilə konseptual xarakterli kompleks tədbirlərə ehtiyac vardır.

Alimlərin proqnozuna görə, qlobal kommunikasiya sistemlərinin köməyilə milli dillərin "çirklənməsi” və bir-birinə nüfuz etməsi nəticəsində mədəniyyətə kobud davranış, ünsiyyət formaları, cahillik, pis vərdiş və yad dəb elementləri aşılanır. Hər bir canlı dilin arxasında onun ifadə zənginliyinin əks etdirən mədəniyyət durur.

Müasir dövrdə qarşımızda həm ümumelmi, həm ümumsosial və həm də fəlsəfi əhəmiyyətə malik nəhəng bir problem durur. Belə ki, son onillikdə qlobal kommunikasiya 


\section{“Informasiya tohlükosizliyinin aktual multidissiplinar elmi-praktiki problemlori” IV respublika konfransı, 14 dekabr 2018-ci il}

sistemlərinin təsiri altında bir çox Azərbaycan sözləri kütləvi informasiya vasitələrində, danışıq dilində, dövlət sənədlərində və s. yabancı sözlərlə əvəz olunmuşdur.

YUNESKO-nun baş konfransının qəbul etdiyi "Çoxdilliliyin inkifafi, istifadə olunması və kiberfəzaya ümumi çıxış haqqında tövsiyyə" adlı sənəddə deyilir: Təşkilatlara üzv ölkələr dilin, xüsusilə ana dilinin kiberfəzada tədrisinə yardım etməklə, son dərəcə vacib bir məsələ olan dilin kiberfəzadan sıxışdırılıb çıxarılmaması üçün fəal milli siyasət işləyib hazırlamalidır [1].

\section{DİLIN İNKISSAFINDA TERMINLORİN ROLU}

Qloballaşma dövründə terminologiya elmi sürətli inkişaf dövrünü yaşayır. Bu hər şeydən əvvəl, onunla bağlıdır ki, indi elmi-texniki tərəqqi müasir cəmiyyətin hərəkətverici qüvvələrindən biridir. Ona görə də cəmiyyətdə, ictimai həyatda, elmi-texniki tərəqqidə baş verən hər bir hadisə və elmi yeniliklər dildə öz əksini tapır.

Beləliklə, cəmiyyətdə insanlar arasında ünsiyyətin əsas forması kimi çıxış edən dil, bu cəmiyyətin müxtəlif sosial qruplarının təsirinə məruz qalaraq zənginləşir. Bununla da dilin lüğət tərkibinin ən çevik hissəsi olan terminologiyada daim inkişaf prosesi gedir. Qeyd etmək lazımdır ki, hər bir elm sahəsi üç əsas anlayış sistemindən:

- onun məzmununu təşkil edən, özündə əks etdirən bir çox faktların toplusundan;

- onun nəticəsində meydana çıxan təsəvvürlərdən;

- bu təsəvvürlərin ifadə olunduğu terminlərdən təşkil olunur [2]. Elmi biliklərin, ayrı-ayrı elm sahələrinin inkişafında dil təsadüfi funksiya daşımır, dil hər bir elmin struktur elementlərindən biri kimi meydana çıxır. Deməli, elmi dil vahidləri məhz terminologiya vasitəsilə elmə daxil olur.

Hazırk1 informasiya mübadiləsi prosesinin ifrat sürətliliyi dil vahidlərinin terminologiya vasitəsilə elmə daxil olmasına mane olur. Buna görə də, terminologiyada baş verən proseslərdən ən əsası yeni terminlərin yaranması və onların dünya dillərində yer almasıdır. Müasir dövr terminologiyasında termin yaradıcılığ 1 daha çox beynəlxalq dil istiqamətində inkişaf etməsi ilə səciyyələnir. Məsələn, yeni terminlərin yaradılmasında ingilis dilinin aparıcı mövqeyə malik olması danılmazdır. Dilin dominantlığını şərtləndirən əsas cəhət elmi fikirlərin, məlumatların bu dildə yazılması və yayılmasıdır. İnternet xidmətindən istifadə yeni anlayışlara uyğun terminlərin İnternet vasitəsi ilə ingilis dilindən götürülməsinə şərait yaradır. Tədqiqatçılar yeni terminlərdən istifadəyə fərqli şəkildə yanaşırlar. Belə ki, bəziləri terminlərin öz dillərində qarşılığını axtarıb tapmağa səy edir, dilin öz vasitələrindən istifadə etməklə yeni termin yaratmağa çalışır, digər qismi alınma terminlərə, başqa qismi isə kalka üsulu(kalkaetmə, qeyri dillardən tərcümə prosesi) ilə termin yaradıcılığına üstünlük verir. $\mathrm{Bu}$ problemlər ayr1-ayrı elm sahələri ilə bağlı terminoloji mərkəzlərin yaranmasını zəruri edir [2].

Hal-hazırda qloballaşan dünyanın yeni çağırışları şəraitində elmi-texniki tərəqqinin və termin yaratmanın sürətli inkişafı xüsusi əhəmiyyət kəsb edir. Azərbaycan da bu prosesin müəyyən neqativ təsirlərinin qarşısını almaqla milli dilin təmizliyini qorumağa cəhd edir. Hazırda dünyada 20 mindən çox terminoloji standart mövcuddur. Onların əsas hissəsi inkişaf etmiş sənaye ölkələrində yaradılmış milli standartlardır. Azərbaycan dilinin funksional imkanlarının inkişafı istiqamətində məqsədyönlü dövlət siyasəti həyata keçirilmiş, bu dil dövlət və cəmiyyət həyatının bütün sahələrində geniş istifadə edilir. Azərbaycan dilinin leksik sistemində terminlər xüsusi əhəmiyyətə malik olmaqla bir çox hallarda onlara ümumişlək sözlərdən daha çox ehtiyac duyulur. Elm və texnikanın bütün sahələrində terminlər informasiya və bilik əldə etmək üçün xüsusi əhəmiyyət daşıyır. Terminologiyanı dərindən mənimsəmədən hər hansı elm sahəsində uğur əldə etmək qeyri-mümkündür [3].

Qeyd edək ki, qloballaşma şəraitində terminologiya strateji resurs olmaqla ölkənin inkişafında vacib rol oynayır. Ölkə vətəndaşlarının səmərəli iqtisadi, texniki və elmi ünsiyyət bacarıqları düzgün və standartlaşdırılmış terminologiyadan istifadə ilə inkişaf etdirilir. İstənilən ölkənin terminologiya təcrübəsi müxtəlif sahələrdə ünsiyyəti genişləndirir və rəsmi dilin funksional dil imkanlarını genişləndirir.

Azərbaycan Respublikası Prezidentinin 23 may 2012-ci il tarixli Sərəncamı ilə AR Nazirlər Kabineti yanında Terminologiya Komissiyasının yaradılması terminologiya fəaliyyətinə olan məsuliyyəti daha da artırdı. Belə ki, Terminologiya Komissiyası təkcə respublikada deyil, respublikadan kənarda da Azərbaycan dilinin qorunması istiqamətində mühüm işlərin həyata keçirilməsinə təkan verdi [4].

Azərbaycan Respublikası Prezidenti İlham Oliyevin 9 aprel 2013-cü il tarixli Sərəncamı ilə təsdiq olunmuş "Azərbaycan dilinin qloballaşma şəraitində zamanın tələblərinə uyğun istifadəsinə və ölkədə dilçiliyin inkişafına dair Dövlət Proqramı"nda müvafiq qurumlar qarşısında mühüm vəzifələr qoyulmuşdur. Azərbaycan dilinin öyrənilməsi və təbliği sahəsində informasiya-kommunikasiya texnologiyalarının (İKT) tətbiqi ilə bağlı müddəalarla əlaqədar olaraq qarşıya qoyulan vəzifələri yerinə yetirmək məqsədilə, AMEA İnformasiya Texnologiyaları İnstitutunda da məqsədyönlü işlər aparılmıs, institutun alim və mütəxəssisləri tərəfindən Milli Terminoloji İnformasiya Sisteminin (MTİS) konsepsiyası və veb-portalı hazırlanmışdır [5].

\section{QLOBALLAŞMA KONTEKSTINDD DİL Və TӘHLÜKӘSIZLIK}

Qloballaşma prosesi dilin təhlükəsizliyinə və inkişafina müsbət təsir etməklə yanaşı mənfi təsir də göstərə bilər. Prosesin müsbət təsiri dilin leksik vahidinin, onun yeni anlam tərzinin və mədəniyyətin zənginləşməsində özünü biruzə verir. Hal-hazırda milli dilə münasibətdə onun mənfi təsirləri daha çox narahatçılıq yaradır.

Qeyd etmək lazımdır ki, dil təhlükəsizliyi anlayışı elmi ədəbiyyatda hələ sistemli təsviri olmayan nisbətən yeni bir anlayışdır. Dilin təhlükəsizliyi milli təhlükəsizlik, informasiya təhlükəsizliyi, linqvistik suverenlik və dil siyasəti problemləri kontekstində tez-tez müzakirə olunur. 


\section{“Informasiya tohlükosizliyinin aktual multidissiplinar elmi-praktiki problemlori” IV respublika konfransı, 14 dekabr 2018-ci il}

Dil təhlükəsizliyinə söykənən akademik müzakirələrdə qeyd olunur ki, hər növ təhdidə uyğun bir obyektin olması və onun təhlükəsizliyinin təmin edilməsi əsas şərtlərdən biridir. Başqa sözlə, həm dilin özünün təhlükəsizliyinin, həm də onun digər növ təhlükəsizliklərin təmin edilməsindəki rolundan danışmaq olar. Məlumdur ki, 2011-ci ildə ABŞ-da sentyabr hadisələrindən sonra Nyu-Yorkdakı Dünya Ticarət Mərkəzinin binalarına hücumun qarşısını ala biləcək sənədlərin məzmununu peşakarcasına dari, urdu, hindi dillərindən tərcümə və şərh edə bilən təcrübəli tərcüməçilərin çatışmamasından ABŞ-1n milli təhlükəsizliynə təhdid kimi başa düşüldü və çox danışıldı [6].

1970-1980-ci illərdə Fransada ingilis dilinin sürətlə yayılması, cəmiyyət tərərfindən millətin ana dilinin itkisi təhlükəsi kimi qəbul edildi və 1994-cü ildə fransız dilinin qorunması haqqinda qanun qəbul edildi (C.Tubonun qanunu). Həmin qanunun Parisin meri J.Şırak tərəfindən məişətə tətbiqi Paris küçələrində ingilis dilində olan bütün lövhələrin çıxarılmasına, hətta ingilis firmalarının adlarının fransiz dilinə tərcüməsinə gətirib ç1xard1 [7].

Hal-hazırda kiçik dillər daxil olmaqla bütün dillərin saxlanması və inkişafı Avropa Birliyinin rəsmi dil siyasəti kimi elan edilir. Buna nail olmağın yollarından biri hətta yetkinlik yaşlarında ikən insanların birdən çox xarici dil mənimsəməsi və hər zaman öyrənməkdə davam etməsidir. 1990-c1 illərin əvvəllərindən etibarən dominant olan və bir sira Avropa dillərini öz sözləri ilə dolduran ingilis dilinin öyrənilməsindən başqa bir neçə xarici dili öyrənmək zərurəti xüsusilə vurğulanır [8]

Rusiya Federasiyasının İnformasiya Təhlükəsizliyi Doktrinasında dil informasiya təhlükəsizliyi obyektlərindən biri hesab olunur [9]

Biliklər iqtisadiyyatına əsaslanan cəmiyyət üçün informasiya bərabərsizliyi müxtəlif ölkə (bölgə) əhalisinin informasiya mənbələrinə və informasiya texnologiyalarına qeyri-bərabər əlyetərliyi və ya informasiyanın İnternet səbəkələrində təqdim olunan dillərini bilmədikləri təhlükə hesab olunur. Belə ki, dil təhlükəsizliyi ölkədə sosiolinqvistik vəziyyətlə müəyyənləşdirilən çoxölçülü və spesifik xüsusiyyəti olan bir anlayışdır.

Ekspertlər və alimlərin fikrincə bu proseslər milli birliyin, mənəviyyatın və ölkənin intellektual potensialının məhv edilməsinə gətirib çıxara bilər. Beləliklə, dilin təhlükəsizliyinin təmin edilməsi milli təhlükəsizliyin əsas şərtlərindən biridir. Dil siyasəti, cəmiyyətdə və dövlətdəki dil problemlərini həll etmək üçün ideoloji prinsiplər və praktik tədbirlər məcmusu kimi, dilin təhdidlərdən qorunması üçün nəzərdə tutulmuşdur [10].

Hüquq linqvistikası baxımindan dil təhlükəsizliyinin xarakteristikası N.D.Qolevın(rus dilçi alim) məruzəsində verilmişdir. Müəllif dil təhlükəsizliyi kateqoriyasını dilin hüquqi məsələləri ilə əlaqələndirir və danışıqda xuliqanlıq (nalayiq sözlər), firıldaqçılıq (dilin manipulyasiya istifadəsi, yalan və / və ya dəyişmə taktikası) hallarında onun pozulmasını iki aspektdə təhlil edir. Hüquqi paradiqma çərçivəsində dilin təhlükəsizliyi danışıq və ya söz oğurluğu (plagiat) ola bilər. Linqvistik paradiqma çərçivəsində isə dil təhlükəsizliyi anlayışı normativ tənzimləmə və qiymətləndirmələrin puristik(dili olduğu kimi, dəyişməz vo təmiz şəkildo saxlamă̆a çalışaraq, həp cür yeniliyə qarşı mübarizədə ifrata varma), qadağanedici başlanğıcının zəiflətmək meyli ilə bağlıdır [11]

\section{NӘTİCə VӘ TӘKLİFLӘR}

Nəticədə dil təhlükəsizliyi anlayışı ilə tolerantlıq anlayışının sıx bağlı olduğu məlum olur. Dil tolerantlığının səviyyəsi şəxsi və ya qrup tərəfindən müəyyən olunmuş qaydalar və üstünlükləri ilə təyin edilə bilər. Məsələn, şaxtaçılar və ya maşınqayırma sahəsinin mütəxəssisləri ilə müqayisədə kompüter mütəxəssislərində və ya beynəlxalq audit firmalarının əməkdaşlarında peşəkar ünsiyyətdə ingilis dilindən alınmalara görə (alınma sözlərə) tolerantlıq səviyyəsi ölçüyə gəlməz səviyyədə yüksəkdir [12].

Akademik cəmiyyətin müxtəlif sahə nümayəndələri ingilis dilinin elmi sahədə genişlənməsini (yayılmasını) fərqli şəkildə qiymətləndirə bilərlər. Hər bir şəxs (qrup) ingilis dilinin elmi terminoloji sahəsinin genişlənməsinə tolerant yanaşa bilər və rus mətbuatında amerikanizmlərin (amerikalılarda ingilis dilinin xüsusiyyəti) hakimiyyətini qətiyyətlə pisləyə bilər və s.

Beləliklə, dil təhlükəsizliyinin və dil tolerantlığının bu və ya digər aspektlərinin aktuallaşdırılması həmişə sosiolingvistik kontekstdə müəyyən edilir.

Qeyd etmək lazımdır ki, dilin təhlükəsizliyinin qorunması istiqamətində Prezident İlham Oliyevin fərmanı ilə Dövlət Dil Komissiyası yanında Monitorinq Mərkəzinin yaradılması bu sahədə meydana çıxan bir sıra problemlərin aradan qaldırılmasında mühüm rol oynayacaq.

Azərbaycanın dünya informasiya məkanına fəal inteqrasiya olunmasını, bu məkanda mədəniyyətimizin, elmimizin, dilimizin, tariximizin və s. özünə layiqli yer tutmasını təmin etmək üçün aşağıdakı işlərin həyata keçirilməsi məqsədəuyğun hesab edilitr:

- Azərbaycan dilli İnternet resursların ildə bir dəfə monitorinqi aparılmalı, dərin elmi təhlil aparıldıqdan sonra, çatışmamazlıqlar, problemlər müəyyənləşdirilməli, onların aradan qaldırılması üçün tədbirlər planı işlənib hazırlanmalıdır;

- milli İnternet resursları İKT-nin yeni nailiyyətləri (xüsusilə İnternetlə bağlı) nəzərə alınmaqla yenidən qurulmalı, onların keyfiyyəti, informasiya yükü, dizaynı, çevikliyi yüksəldilməlidir;

- dilçilik elminin müasir inkişaf meyillərini nəzərə almaqla, elmi tədqiqatların prioritet istiqamətləri müəyyənləşdirilməlidir;

- dilçilik sahəsində dünyanın aparıcı elmi mərkəzləri ilə əməkdaşlıq inkişaf etdirilməlidir;

- dilin inkişafı və tədrisi məsələləri uzlaşdırılmalı və təkmilləşdirilməlidir;

- dilçi alimlərin müasir informasiya və kommunikasiya texnologiyalarının istifadəsində iştirakı təmin edilsinməlidir; 


\section{“Informasiya tohlükosizliyinin aktual multidissiplinar elmi-praktiki problemlori” IV respublika konfransl, 14 dekabr 2018-ci il}

- qlobal tendensiyaların dilə neqativ təsirlərini minimuma endirmək məqsədilə konseptual xarakterli kompleks tədbirlərə ehtiyac vardir;

- dilin kiberfəzadan sıxışdırılıb çıxarılmaması üçün fəal milli siyasət işləyib hazırlanmalıdır;

- kütləvi informasiya vasitələrində, tədrisdə, çap olunan kitablarda, Azərbaycan dili İnternet saytlarında IKT üzrə terminlərin işlədilməsində hökm sürən özbaşınalığa son qoymaq məqsədilə bu sahədə Azərbaycan Milli Elmlər Akademiyası Rəyasət Heyəti yanında Terminologiya Komissiyası tərəfindən təsdiq olunmuş vahid, böyük həcmli terminoloji lüğət hazırlanmalı, çap olunmalı və həm də İnternetdə yerləşdirilməlidir (xüsusi saytda).

Elmi terminologiyanın yaradılması üçün Azərbaycan dili hər cür imkana malikdir. Hal-hazırda AMEA İnformasiya Texnologiyaları İnstitutunda terminoloji lügətin hazırlanması üzərində işlər aparılır.

\section{ӘDӘBIYYYAT}

11] Kazımov T.H. Azərbaycan dili və virtual mokan. Ekspress-informasiya. İnformasiya comiyyəti seriyası, Bak1: "Informasiya Texnologiyaları" nəşriyyatı, 2009.

[2] Terminologiya məsələləri. Bak1, Elm, 2015, http://azkurs.org/terminologiya-meseleleri-1-v2.html

[3] İmamverdiyev Y.N. Основные термины информационной безопасности, www.genderi.org/osnovnie-termini-informacionnojbezopasnosti.html

[4] Sayalı Sadıqova Azərbaycan dili terminologiyası, www.science.gov.az/news/open/142

[5] Milli terminoloji veb-portalın təqdimat mərasimi, www.science.gov.az/news/open/7538

[6] Language Boot Camp http://italian.about.com/library/weekly/aa091102a.htm

[7] Какая страна приняла первой закон о защите родного языка? //http://otvet.mail.ru/question/17827149

[8] Европейский день языков

https://ru.wikipedia.org/wiki/\%D0\%95\%D0\%B2\%D1\%80\%D0\%BE\%D0 \%BF\%D0\%B5\%D0\%B9\%D1\%81\%D0\%BA\%D0\%B8\%D0\%B9 \%D0\% B4\%D0\%B5\%D0\%BD\%D1\%8C_\%D1\%8F\%D0\%B7\%D1\%8B\%D0\%B $\mathrm{A} \% \mathrm{D} 0 \% \mathrm{BE} \% \mathrm{D} 0 \% \mathrm{~B} 2$

[9] Доктрина информационной безопасности Российской Федерации (утв. Президентом РФ 09.09.2000 № ПР-1895) // http://infopravo.by.ru/ fed2000/ch03/akt14873.shtm

[10] Колин К. К. Русский язык и актуальные проблемы национальной безопасности // Вестник Челябинской государственной академии культуры и искусств, 2007, № 2(12), с. 131-147.

[11] Голев Н.Д. Экспертиза конфликтных текстов в лингвистической и юридической парадигмах // http://lingvo.asu.ru/golev/articles/v64.html

[12] Гриценко Е.С., Гронская Н.Э. Гипертолерантность, или о либерализме в использовании языка // Вестник Минского государственного лингвистического университета, 2009, вып. 3(40), c. $7-15$.

\section{DEVELOPMENT TRENDS AND SAFETY OF LANGUAGE IN TERMS OF GLOBALIZATION}

S.Abdullayev ${ }^{1}$, T. Kazımov ${ }^{2}$, S. Abasova ${ }^{3}$

${ }^{1,2}$ Institute of Information Technology of ANAS,

Baku, Azerbaijan

$$
{ }^{1} \text { sayyar.abdullayev@yandex.ru, }{ }^{2} \text { tofig@mail.ru, }
$$$$
\text { 3abasova.sudaba@gmail.com }
$$

Abstract - The article reviews the concept of language security in a globalized world in the context of national security, information security, linguistic sovereignty and language policy issues. The factors influencing the tendency of language development in terms of globalization, the role and security of terms in the protection of the national purity of the language is investigated.

Keywords - language safety; globalization; terminography; linguistic sovereignty; sociolinguisfics 